\title{
Post-Decontamination and Dismantlement (D\&D) Characterization Report for CFA-669 Site
}

\author{
D. L. Smith
}

Published January 1995

Idaho National Engineering Laboratory Lockheed Idaho Technologies Company

Idaho Falls, Idaho 83415

Contract DE-AC07-94ID13223 



\section{ABSTRACT}

The Post-Decontamination and Dismantlement Characterization Report for

CFA-669 presents the results of surveys conducted by EG\&G Idaho, Inc., at the Idaho National Engineering Laboratory. These surveys were conducted to determine the levels of radionuclides, metals, volatile organic compounds, and semivolatile organic compounds remaining after the building had been decontaminated and dismantled. This report documents the findings of the surveys.

\section{DISCLAIMER}

This report was prepared as an account of work sponsored by an agency of the United States Government. Neither the United States Government nor any agency thereof, nor any of their employees, makes any warranty, express or implied, or assumes any legal liability or responsibility for the accuracy, completeness, or usefulness of any information, apparatus, product, or process disclosed, or represents that its use would not infringe privately owned rights. Reference herein to any specific commercial product, process, or service by trade name, trademark, manufacturer, or otherwise does not necessarily constitute or imply its endorsement, recommendation, or favoring by the United States Government or any agency thereof. The views and opinions of authors expressed herein do not necessarily state or reflect those of the United States Government or any agency thereof. 


\section{DISCLAIMER}

Portions of this document may be illegible in electronic image products. Images are produced from the best available original document. 


\section{SUMMARY}

This report presents results of post-decontamination and dismantling (D\&D) characterization surveys performed by EG\&G Idaho, Inc. (EG\&G Idaho), at Central Facilities Area (CFA)-669, which was the Hot Laundry Facility. The site was characterized to determine and document the radiological and chemical conditions of the site following D\&D and to determine if the site satisfies the release criteria. Constructed in 1950, CFA-669 served as the "hot" and "cold" laundry for Idaho National Engineering Laboratory site contractors until the boiler exploded in 1981. The building was shut down at that time. Before D\&D activities began in 1992, the facility was characterized and the results documented. D\&D activities were completed in July 1994.

The post-D\&D radiological characterization consisted of radiation measurements and analyses of soil samples to identify man-made radionuclides and determine the specific activity of each sample. The chemical characterization consisted of toxicity characterization leaching procedure (TCLP) analysis for metals and for volatile and semivolatile organic contamination. The post-D\&D characterization was performed in two phases by EG\&G Idaho's Environmental Monitoring Unit.

Phase I characterization consisted of sampling and analysis of the trench and berm formed during excavation of the 8-in. contaminated sanitary sewer line on the north side and beneath Room 108 of CFA-669. Phase II characterization consisted of sampling and analyses of the entire CFA-669 site following backfilling of the trenches and gridding of the area followed by an area radiological survey.

Analyses of the soil samples for Phases I and II consisted of TCLP metals, volatile organic analysis (VOA) semi-VOA, alpha and gamma spectrum and strontium-90. All the chemical analyses were performed according to analytical procedure SW-846. The results of Phases I and II analyses were validated by the EG\&G Idaho Sample Management Office (SMO).

The results of the gamma spectrum analysis and the strontium-90 and alpha spectrum analyses for Phase I indicated that the CFA-669 site meets release criteria specified in DOE Order 5400.5 .

The Phase I samples were analyzed for TCLP metals, TCLP volatile organic compounds (VOCs), and TCLP semi-VOCs. The results of these analyses were validated by the EG\&G Idaho SMO. Lockheed Idaho Technologies Company (LITCO, formerly EG\&G Idaho until October 1, 1994) Environmental Monitoring reviewed the analytical result. The review indicated that all contaminant concentrations were below the regulatory level found in 40 CFR 261.24, Table 1.

The results of the gamma spectrum analysis and strontium- 90 and alpha spectrum analyses performed on two select Phase II samples indicated that the CFA-669 site meets release criteria specified in DOE Order 5400.5.

In addition to the radiological analyses of samples collected during Phase $\Pi$, an area survey was performed using the Global Positioning Radiometric Scanner. The results of this area survey indicated nothing detected above general background, $8 \mu \mathrm{R} /$ hour, at the CFA-669 site. 
The Phase II samples were analyzed for TCLP metals, TCLP VOCs, and TCLP semi-VOCs. The results of these analyses were validated by the EG\&G Idaho SMO. A review of the analytical results was performed by LITCO Environmental Monitoring. The review indicated that all contaminant concentrations were below the regulatory level found in 40 CFR 261.24, Table 1. 


\section{CONTENTS}

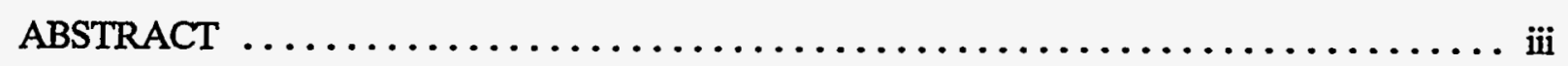

SUMMARY $\ldots \ldots \ldots \ldots \ldots \ldots \ldots \ldots \ldots \ldots \ldots \ldots \ldots \ldots \ldots \ldots \ldots \ldots \ldots \ldots \ldots$

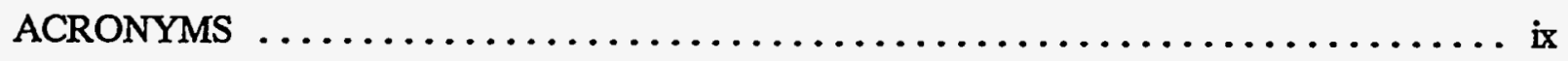

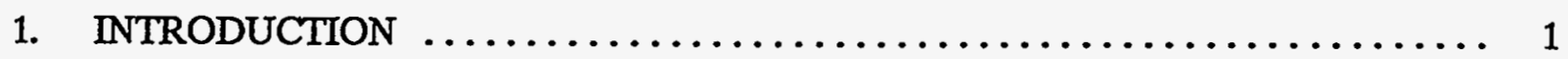

2. HISTORY AND BACKGROUND $\ldots \ldots \ldots \ldots \ldots \ldots \ldots \ldots \ldots \ldots \ldots \ldots \ldots \ldots \ldots \ldots \ldots$

3. SITE PHYSICAL DESCRIPTION $\ldots \ldots \ldots \ldots \ldots \ldots \ldots \ldots \ldots \ldots \ldots \ldots \ldots$

4. CHARACTERIZATION PERFORMED $\ldots \ldots \ldots \ldots \ldots \ldots \ldots \ldots \ldots \ldots \ldots$

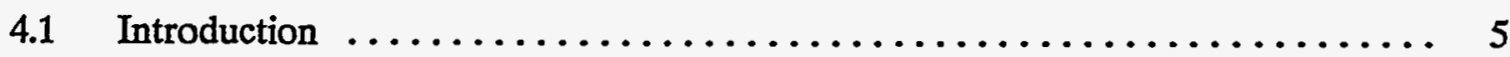

4.2 Phase I Characterization $\ldots \ldots \ldots \ldots \ldots \ldots \ldots \ldots \ldots \ldots \ldots \ldots \ldots, 5$

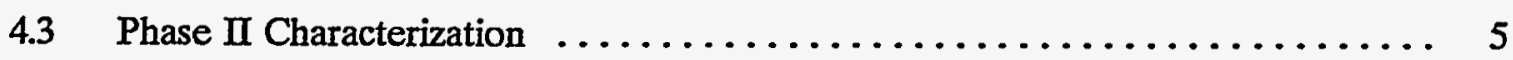

5. CHARACTERIZATION RESULTS $\ldots \ldots \ldots \ldots \ldots \ldots \ldots \ldots \ldots \ldots \ldots \ldots \ldots$

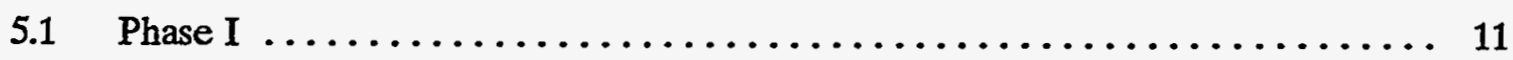

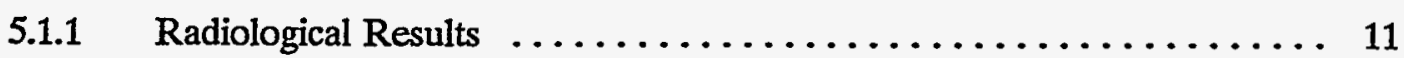

5.1.2 Chemical Results .......................... 11

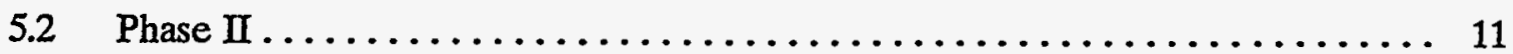

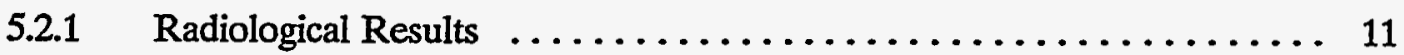

$5.2 .2 \quad$ Chemical Results ........................... 17

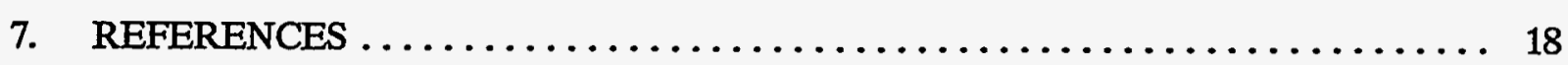

\section{FIGURES}

1. CFA and the original location of CFA-669. $\ldots \ldots \ldots \ldots \ldots \ldots \ldots \ldots \ldots \ldots \ldots$

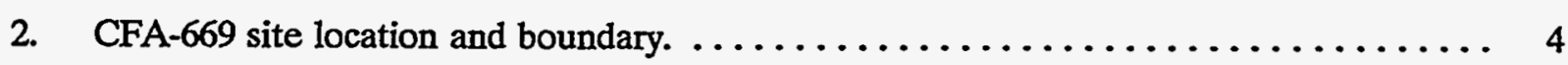

3. Phase I sample locations. $\ldots \ldots \ldots \ldots \ldots \ldots \ldots \ldots \ldots \ldots \ldots \ldots \ldots \ldots \ldots \ldots \ldots \ldots \ldots$ 
4. CFA- 669 site following gridding of the area. $\ldots \ldots \ldots \ldots \ldots \ldots \ldots \ldots$

5. CFA- 669 site being radiologically surveyed using the GPRS. $\ldots \ldots \ldots \ldots \ldots \ldots$

\section{TABLES}

1. Phase II samples and the corresponding grid number. $\ldots \ldots \ldots \ldots \ldots \ldots \ldots$

2. Results of Phase I gamma spectrum analyses. $\ldots \ldots \ldots \ldots \ldots \ldots \ldots \ldots \ldots$

3. Results of Phase I strontium-90 and alpha spectrum analyses $(\mathrm{pCi} / \mathrm{g}) \ldots \ldots \ldots \ldots$

4. Results of Phase $I I$ gamma spectrum analysis. $\ldots \ldots \ldots \ldots \ldots \ldots \ldots \ldots \ldots$

5. Results of Phase II strontium-90 and alpha spectrum analyses (pCi/g) . . . . . .. 16 


\section{ACRONYMS}

ARDC Environmental Restoration Administrative Record and Document Control

ATI Analytical Technologies Incorporated

CFA Central Facilities Area

D\&D Decontamination \& Dismantling

EG\&G Idaho EG\&G Idaho, Inc. (Lockheed Idaho Technologies Cornpany as of October 1, 1994)

GPRS · Global Positioning Radiometric Scanner

INEL Idaho National Engineering Laboratory

IVC Independent Verification Contractor

LITCO Lockheed Idaho Technologies Company

RML Radiation Measurements Laboratory

RWMC Radioactive Waste Management Complex

SMO Sample Management Office

TCLP Toxicity Characterization Leaching Procedure

TRA Test Reactor Area

VOA Volatile Organic Analysis

VOC Volatile Organic Compound 


\section{Post-Decontamination and Dismantlement (D\&D) Characterization Report for CFA-669 Site}

\section{INTRODUCTION}

This report presents results of post-decontamination and dismantling (D\&D) characterization surveys performed by EG\&G Idaho, Inc. (EG\&G Idaho), at Central Facilities Area (CFA)-669, which was the Hot Laundry Facility. The site was characterized to determine and document the radiological and chemical conditions of the site following $D \& D$ and to determine if the site satisfies the release criteria.

The radiological characterization consisted of radiation measurements and analyses of soil samples to identify man-made radionuclides and determine the specific activity of each sample. The chemical characterization consisted of toxicity characterization leaching procedure (TCLP) analysis for metals and for volatile and semivolatile organic contamination. 


\section{HISTORY AND BACKGROUND}

Building CFA-669 was constructed in 1950 to serve as the "hot" and "cold" laundry for Idaho National Engineering Laboratory site contractors. It served as a laundry until the boiler exploded in 1981, after which the facility remained shut down through 1992. The original location of CFA-669 relative to the Central Facilities Area is shown in Figure 1.

Before D\&D activities were started in December 1992, the facility was characterized and the results are reported in Reference 1. D\&D activities were completed in July 1994. These D\&D activities included removal and disposal of all contaminated and uncontaminated equipment, components, and structures, including underground piping and the building foundation. The area was backfilled and seeded following completion of post-D\&D characterization of the site. 


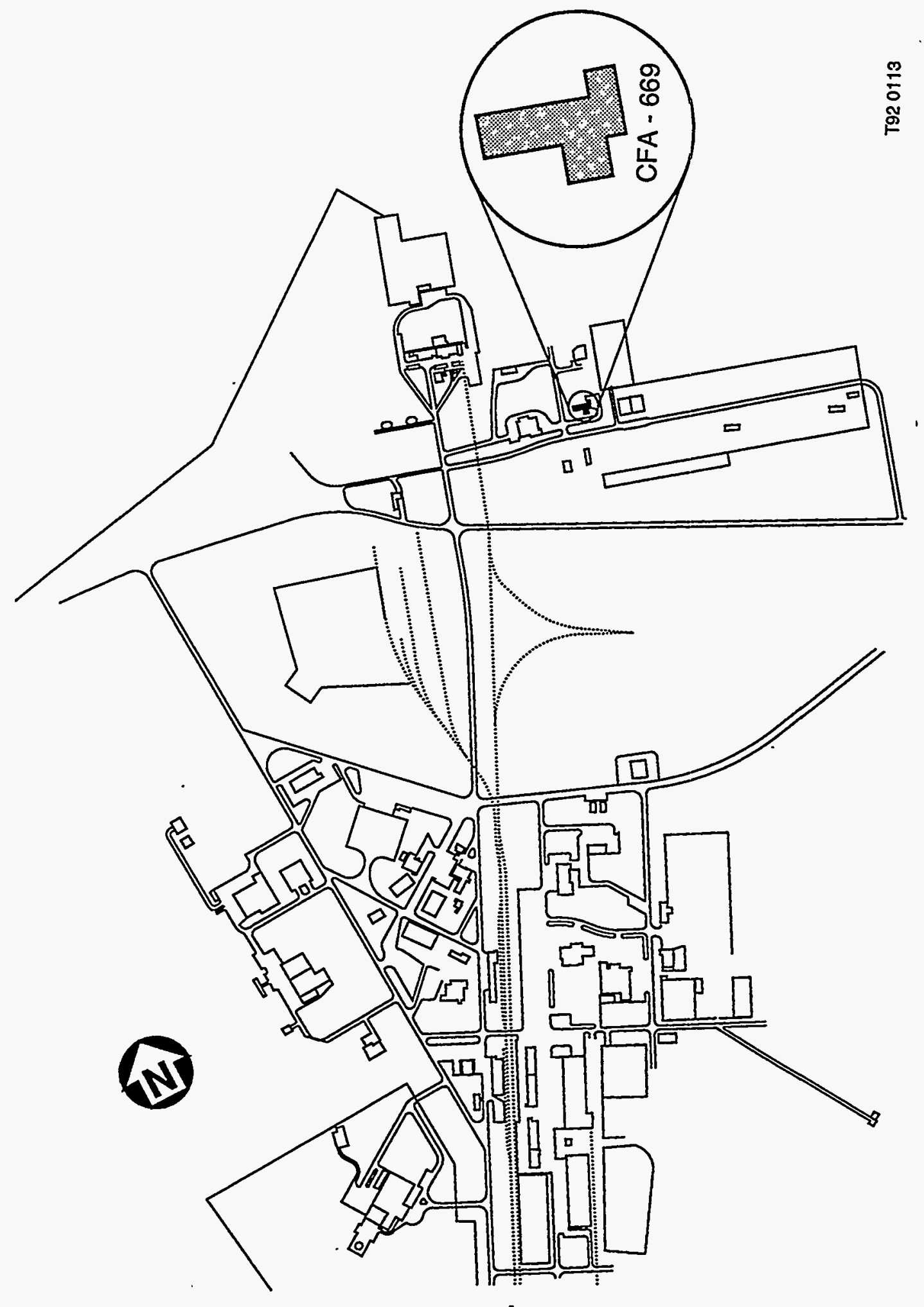

总 


\section{SITE PHYSICAL DESCRIPTION}

The CFA-669 site boundary and location relative to Quebec Avenue and Ohio Street are shown in Figure 2. The original locations of CFA-669 and the contaminated sewer line are also shown in Figure 2 for reference. The site is an area of approximately 0.6 acre.

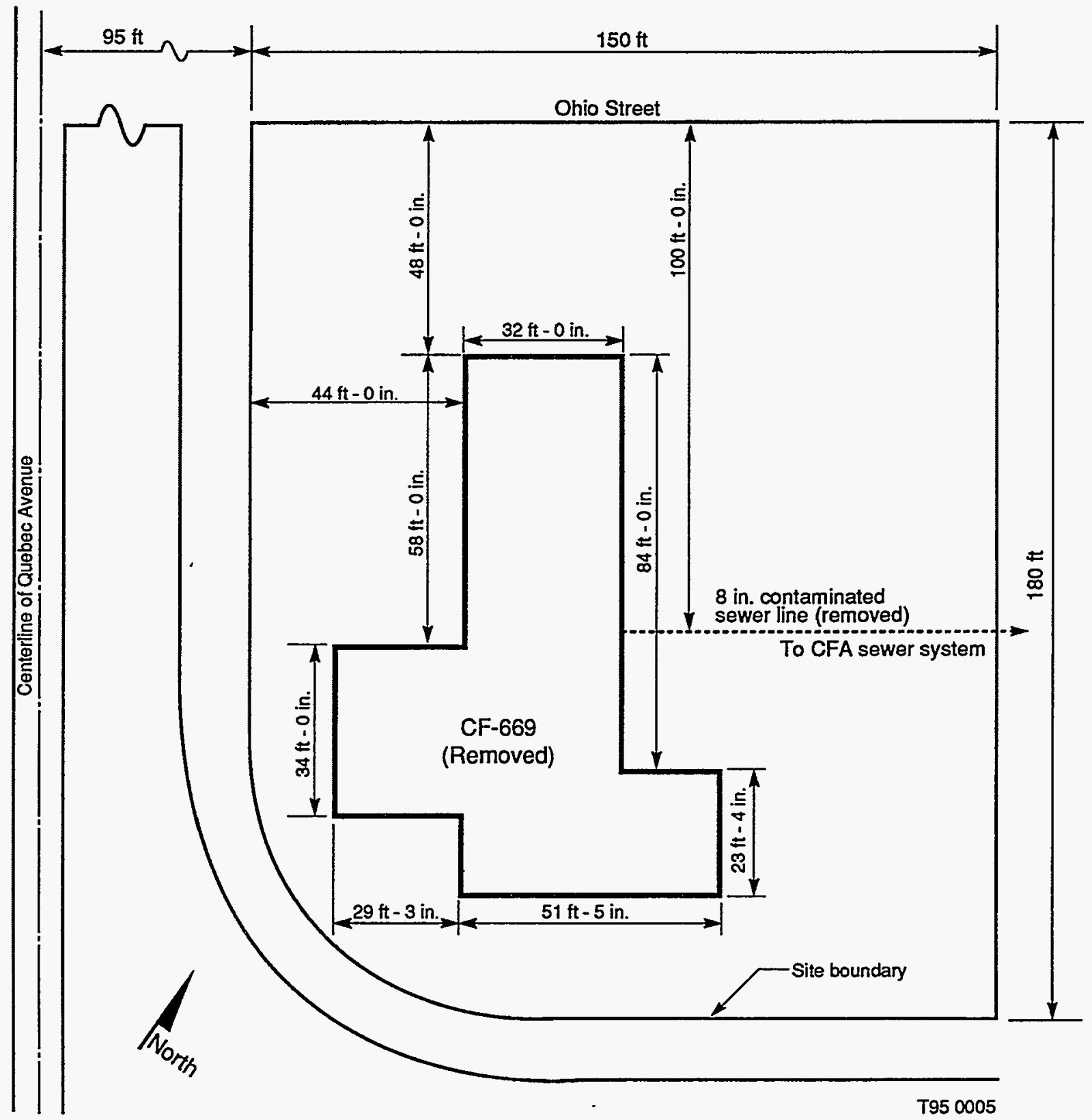

Figure 2. CFA- 669 site location and boundary. 


\section{CHARACTERIZATION PERFORMED}

\subsection{Introduction}

Before starting post-D\&D characterization, all radioactively-contaminated soil detectable by field instruments was removed, boxed, and disposed of at the Radioactive Waste Management Complex (RWMC).

The post-D\&D characterization was performed in two phases. Both phases were performed by EG\&G Idaho's Environmental Monitoring Unit according to Reference 2. Phase I characterization consisted of sampling and analysis of the trench and berm formed during excavation of the 8-in. contaminated sanitary sewer line on the north side and beneath Room 108 of CFA-669 (see Figure 3). Phase II characterization consisted of sampling and analyses of the entire CFA- 669 site after the trenches were backfilled and gridded. The sampling was followed by a radiological survey of the area.

Analyses of the soil samples for Phases I and II consisted of TCLP metals, volatile organic analysis (VOA) semi-VOA, alpha and gamma spectrum and strontium-90. All the chemical analyses were performed according to analytical procedure SW-846. The results of Phase I and Phase II analyses were validated by the Sample Management Office (SMO) and are included in Section 5.

\subsection{Phase I Characterization}

Phase I characterization was performed on the trench and berm formed by excavating the contaminated sewer line and the soil beneath the washer drain trench in the concrete floor of Room 108. The locations where the biased Phase I samples were collected are shown in Figure 3.

\subsection{Phase II Characterization}

After the completion of Phase I sampling, the entire area was backfilled using the soil previously excavated. After the area was backfilled, it was gridded into $15 \times 15$-ft squares and numbered as shown in Figure 4. Then, to choose which grids to sample, 21 grid numbers between 1 and 120 were randomly generated: $43,39,74,95,109,28,71,5,77,72,7,100,66,47,26,60$, $40,84,36,80$, and 14 . The grids with those numbers were sampled.

Each chosen grid was sampled by first obtaining five subsamples ( $0-6$ in. in depth) from each of the four corners and from the center. These subsamples were composited together into a pan. A deep subsample (6-24 in.) was then taken from the center hole and composited with the other subsamples in the bucket. The VOA sample was collected from an undisturbed portion of the grid (subject to sampler's discretion) at a depth of 0 to 6 in. using a scoop or equivalent. This same procedure was used to sample each chosen grid. One replicate sample set and one split (for the independent verification contractor) sample set were also collected. The replicate and split sample numbers are given in Table 1. After Phase II sampling there were 21 sets of samples, one replicate set, and one split set for a total of 23 sets. 


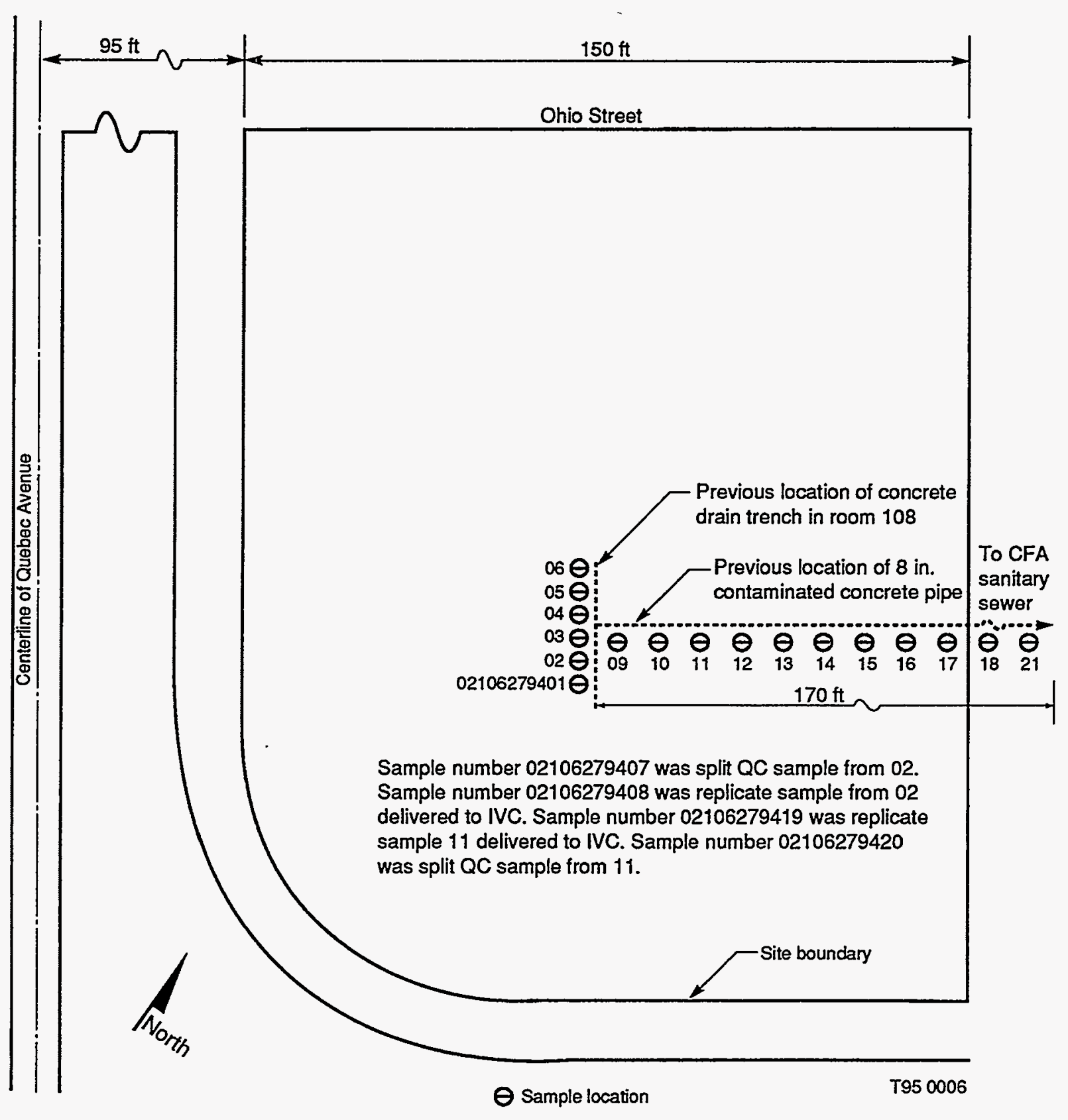

Figure 3. Phase I sample locations. 


\begin{tabular}{|l|l|l|l|l|l|l|l|l|l|l|l|}
\hline \\
\hline
\end{tabular}

Figure 4. CFA-669 site following gridding of the area. 
Table 1 shows the Phase II sample numbers and the grid number where each sample was collected. Samples 02108019412 and 021080191416 were selected for strontium- 90 and alpha spectrum analysis because these samples were collected from grid squares near the contaminated drains. Samples collected in support of this project were submitted for analysis to Analytical Technologies Incorporated (ATI) for Toxicity Characteristic Leaching Procedure (TCLP) metals, TCLP VOCs, semi-VOCs, strontium-90, and alpha spectrum. Samples for gamma spectrum analysis were sent to the Radiation Measurements Laboratory (RML) at the Test Reactor Area (TRA) at the INEL. Note that sample 02108019405 was a replicate and sample 02108019412 was split for the independent verification contractor (IVC).

In addition to soil sampling and analysis during Phase II characterization, an area radiological survey was performed using the vehicle-mounted Global Positioning Radiometric Scanner (GPRS), as shown in Figure 5. The GPRS system integrates a five-channel global positioning system with vehicle-mounted plastic scintillation radiation monitor, and a single-board 386 IBM-compatible computer. Information on the GPRS system can be found in EG\&G Idaho technical report ERA-NRE-93-067. 
Table 1. Phase II samples and the corresponding grid number.

\begin{tabular}{|c|c|}
\hline Grid number & Sample number \\
\hline 5 & 02108019401 \\
\hline 7 & 02 \\
\hline 14 & 03 \\
\hline 26 & 04 \\
\hline 28 & 05 (replicate) \\
\hline 36 & 06 \\
\hline 39 & 07 \\
\hline 40 & 08 \\
\hline 43 & 09 \\
\hline 47 & 10 \\
\hline 60 & 11 \\
\hline 66 & 12 (split for IVC) \\
\hline 71 & 13 \\
\hline 72 & 14 \\
\hline 74 & 15 \\
\hline 77 & 16 \\
\hline 80 & 17 \\
\hline 84 & 18 \\
\hline 95 & 19 \\
\hline 100 & 20 \\
\hline 109 & 21 \\
\hline
\end{tabular}




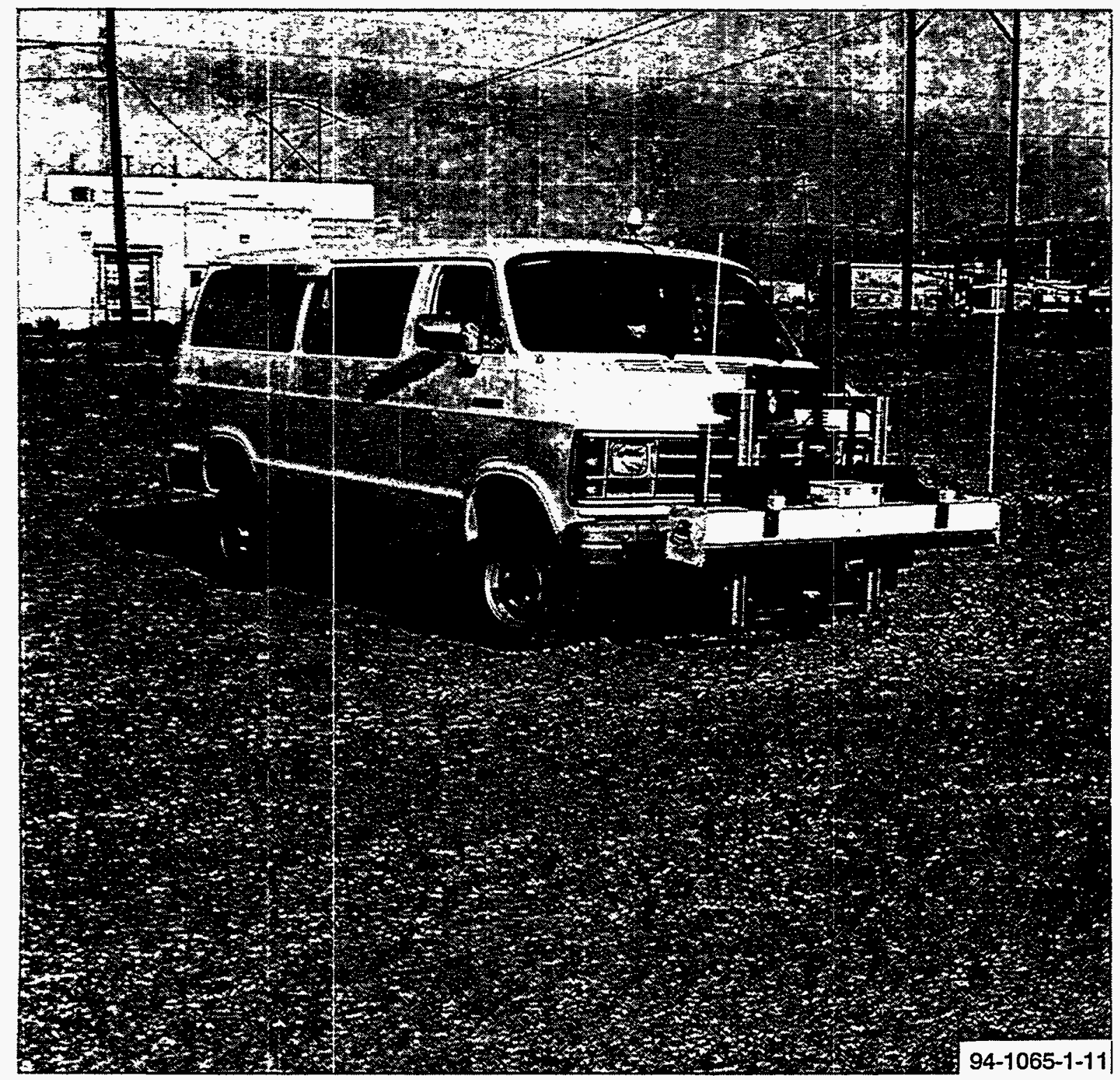

Figure 5. CFA-669 site being radiologically surveyed using the GPRS. 


\section{CHARACTERIZATION RESULTS}

The results of the chemical and radiological analyses and area radiological survey are given in this section.

\subsection{Phase I}

\subsubsection{Radiological Results}

The results of the gamma spectrum analysis performed on all Phase I samples are shown in Table 2. The results of the Strontium-90 and alpha spectrum analyses for Phase $I$ are given in Table 3.

The highest concentration of each detected radionuclide for Phase I was used to determine if the CFA-669 site is releasable per guidelines in DOE Order 5400.5. The peak concentrations were input into the Residual Radioactivity (RESRAD) computer program, version 3.121. The calculation including assumptions is documented in EDF-ER-21, "CFA-669 Site Release Analysis." The RESRAD calculation indicated that the maximum total dose would occur at time $t=10,000$ years and would be 15 mrem/year. The allowable dose per DOE Order 5400.5 is 100 mrem/year.

\subsubsection{Chemical Results}

The Phase I samples were analyzed for TCLP metals, TCLP VOCs, and TCLP semi-VOCs. The results of these analyses were validated by the EG\&G Idaho SMO. Lockheed Idaho Technologies Company (LITCO, formerly EG\&G Idaho) Environmental Monitoring reviewed the analytical result. The review indicated that all contaminant concentrations were below the regulatory level found in $40 \mathrm{CFR} 261.24$, Table 1 . The analytical and validation results were transmitted to the Environmental Restoration Administrative Record and Document Control (ARDC) via D. L. Smith letter to ARDC, memo-to-file, Closure Report for Phase I and Phase II sampling of CFA-669, DLS-7-94, December 7, 1994.

\subsection{Phase II}

\subsubsection{Radiological Results}

The results of the gamma spectrum analysis performed on all Phase II samples are given in Table 4, and the results of the strontium-90 and alpha spectrum analyses performed on two select Phase II samples are given in Table 5.

The highest concentration of each detected radionuclide for Phase II was used to determine if the CFA-669 site is releasable under guidelines in DOE Order 5400.5. The peak concentrations were input into the Residual Radioactivity (RESRAD) computer program, version 3.121 and documented in EDF-ER-21. The calculation indicated the maximum total dose would occur at time $t=10,000$ years and would be 18 mrem/year. The allowable dose according to DOE Order 5400.5 is 100 mrem/year. 
Table 2. Results of Phase I gamma spectrum analyses.

\begin{tabular}{cll}
\hline Sample number & \multicolumn{1}{c}{$\begin{array}{c}\text { Manmade } \\
\text { radionuclides }\end{array}$} & $\begin{array}{c}\text { Specific activity } \\
\text { (pCi/g) }\end{array}$ \\
\hline 02106279401 & None detected & N/A \\
02 & ${ }^{60} \mathrm{Co}$ & $5.8 \pm 1.4 \mathrm{E}-02$ \\
& ${ }^{137} \mathrm{Cs}$ & $6.1 \pm 0.5 \mathrm{E}-01$ \\
03 & ${ }^{137} \mathrm{Cs}$ & $3.7 \pm 0.4 \mathrm{E}-01$ \\
04 & ${ }^{137} \mathrm{Cs}$ & $7.2 \pm 0.7 \mathrm{E}-01$ \\
05 & ${ }^{60} \mathrm{Co}$ & $5.9 \pm 1.4 \mathrm{E}-02$ \\
& ${ }^{137} \mathrm{Cs}$ & $3.7 \pm 0.4 \mathrm{E}-01$ \\
06 & ${ }^{60} \mathrm{Co}$ & $9.0 \pm 0.7 \mathrm{E}-01$ \\
& ${ }^{137} \mathrm{Cs}$ & $5.7 \pm 0.6 \mathrm{E}-01$ \\
07 & None detected & N/A \\
09 & ${ }^{137} \mathrm{Cs}$ & $7.9 \pm 0.8 \mathrm{E}-01$ \\
10 & ${ }^{137} \mathrm{Cs}$ & $2.1 \pm 0.4 \mathrm{E}-01$ \\
11 & ${ }^{137} \mathrm{Cs}$ & $6.0 \pm 2.0 \mathrm{E}-02$ \\
12 & ${ }^{137} \mathrm{Cs}$ & $3.2 \pm 0.5 \mathrm{E}-01$ \\
13 & ${ }^{137} \mathrm{Cs}$ & $1.5 \pm 0.2 \mathrm{E}-01$ \\
14 & None detected & N/A \\
15 & ${ }^{137} \mathrm{Cs}$ & $1.2 \pm 0.2 \mathrm{E}-01$ \\
16 & ${ }^{137} \mathrm{Cs}$ & $2.4 \pm 0.3 \mathrm{E}-01$ \\
17 & None detected & N/A \\
18 & ${ }^{60} \mathrm{Co}$ & $4.7 \pm 1.2 \mathrm{E}-02$ \\
& ${ }^{137} \mathrm{Cs}$ & $1.96 \pm 0.18 \mathrm{E}-00$ \\
& ${ }^{152} \mathrm{Eu}$ & $2.1 \pm 0.3 \mathrm{E}-01$ \\
20 & None detected & N/A \\
21 & None detected & N/A \\
& &
\end{tabular}

1. A "None detected" under "Manmade Radionuclides" means that the analyst determined that no manmade true-positive radionuclides were present in the respective sample(s).

2. The uncertainty associated with any reported activity includes the statistical uncertainty and estimated uncertainties in the detector efficiency and the sample geometry (both are typically 5\%). Uncertainties are propagated in quadrature and expressed as one standard deviation.

3. When a sample's matrix differs radically from that of the calibration standard used by the RML, the measured activity may not accurately represent the true radionuclide concentration in that sample. In such cases, a non-zero estimated bias is applied in place of the estimated sample geometry; this bias is not propagated into the total uncertainty and is listed separately. 
Table 3. Results of Phase I strontium-90 and alpha spectrum analyses (pCi/g).

\begin{tabular}{|c|c|c|c|c|c|c|c|c|c|c|c|c|c|}
\hline $\begin{array}{l}\text { Sample } \\
\text { number }\end{array}$ & ${ }^{241} \mathrm{Am}$ & ${ }^{243} \mathrm{Am}$ & ${ }^{242} \mathrm{Cm}$ & ${ }^{244} \mathrm{Cm}$ & ${ }^{238} \mathrm{Pu}$ & $239 / 240_{\mathrm{Pu}}$ & ${ }^{234} \mathrm{U}$ & ${ }^{235} \mathrm{U}$ & ${ }^{238} 8_{U}$ & ${ }^{228} 8_{T h}$ & ${ }^{230} \mathrm{Th}$ & ${ }^{232} \mathrm{Th}$ & ${ }^{90} \mathrm{Sr}$ \\
\hline $\begin{array}{c}02106279401 \\
.\end{array}$ & $\mathbf{U}$ & $\mathbf{U}$ & $\mathbf{U}$ & $\mathbf{U}$ & $\mathbf{U}$ & $\mathbf{U}$ & $\begin{array}{l}1.077 \pm \\
0.149\end{array}$ & $\begin{array}{l}0.043 \pm \\
0.017\end{array}$ & $\begin{array}{l}1.095 \pm \\
0.151\end{array}$ & $\begin{array}{l}1.315 \pm \\
0.188\end{array}$ & $\begin{array}{l}1.227 \pm \\
0.175\end{array}$ & $\begin{array}{l}1.306 \pm \\
0.186\end{array}$ & $\mathrm{U}$ \\
\hline 02106279402 & $\mathbf{U}$ & $\mathrm{U}$ & $\mathbf{U}$ & $\mathbf{U}$ & $\mathbf{U}$ & $\mathbf{U}$ & $\begin{array}{l}1.293 \pm \\
0.179\end{array}$ & $\begin{array}{l}0.056 \pm \\
0.019\end{array}$ & $\begin{array}{l}1.351 \pm \\
0.182\end{array}$ & $\begin{array}{l}1.365 \pm \\
0.199\end{array}$ & $\begin{array}{l}1.291 \pm \\
0.189\end{array}$ & $\begin{array}{l}1.311 \pm \\
0.191\end{array}$ & $7 \pm 3 \mathrm{E}-01$ \\
\hline 02106279403 & $\mathbf{U}$ & $\mathbf{U}$ & $\mathbf{U}$ & $\mathbf{U}$ & $\begin{array}{l}0.054 \pm \\
0.019\end{array}$ & U & $\begin{array}{l}1.167 \pm \\
0.161\end{array}$ & $\begin{array}{l}0.054 \pm \\
0.017\end{array}$ & $\begin{array}{l}1.261 \pm \\
0.172\end{array}$ & $\begin{array}{l}1.372 \pm \\
0.196\end{array}$ & $\begin{array}{l}1.396 \pm \\
0.198\end{array}$ & $\begin{array}{l}1.358 \pm \\
0.193\end{array}$ & $1.3 \pm 0.4 \mathrm{E}+0$ \\
\hline 02106279404 & $\mathbf{U}$ & $\mathbf{U}$ & $\mathbf{U}$ & $\mathbf{U}$ & $\begin{array}{l}0.065 \pm \\
0.026\end{array}$ & $\begin{array}{l}0.009 \pm \\
0.007\end{array}$ & $\begin{array}{l}1.002 \pm \\
0.148\end{array}$ & $\begin{array}{l}0.043 \pm \\
0.019\end{array}$ & $\begin{array}{l}1.086 \pm \\
0.158\end{array}$ & $\begin{array}{l}1.403 \pm \\
0.200\end{array}$ & $\begin{array}{l}1.313 \pm \\
0.187\end{array}$ & $\begin{array}{l}1.336 \pm \\
0.191\end{array}$ & $8 \pm 3 \mathrm{E}-01$ \\
\hline 02106279405 & UJ & $\mathbf{U}$ & $\mathbf{U}$ & $\mathbf{U}$ & $\mathbf{U}$ & $\mathbf{U}$ & $\begin{array}{l}1.140 \pm \\
0.158\end{array}$ & $\begin{array}{l}0.043 \pm \\
0.017\end{array}$ & $\begin{array}{l}1.205 \pm \\
0.166\end{array}$ & $\begin{array}{l}1.385 \pm \\
0.197\end{array}$ & $\begin{array}{l}1.284 \pm \\
0.183\end{array}$ & $\begin{array}{l}1.300 \pm \\
0.186\end{array}$ & $9 \pm 4 \mathrm{~B}-01$ \\
\hline 02106279406 & $\mathbf{U}$ & U & $\mathbf{U}$ & $\mathbf{U}$ & $\mathbf{U}$ & $\mathbf{U}$ & $\begin{array}{l}1.061 \pm \\
0.147\end{array}$ & $\begin{array}{l}0.056 \pm \\
0.017\end{array}$ & $\begin{array}{l}1.063 \pm \\
0.147\end{array}$ & $\begin{array}{l}1.358 \pm \\
0.198\end{array}$ & $\begin{array}{l}1.257 \pm \\
0.185\end{array}$ & $\begin{array}{l}1.396 \pm \\
0.203\end{array}$ & $1.3 \pm 0.3 \mathrm{E}+0$ \\
\hline 02106279407 & $\mathbf{U}$ & $\mathbf{U}$ & $\mathbf{U}$ & $\mathbf{U}$ & U & $\mathbf{U}$ & $\begin{array}{l}1.169 \pm \\
0.159\end{array}$ & $\begin{array}{l}0.047 \pm \\
0.017\end{array}$ & $\begin{array}{l}1.115 \pm \\
0.152\end{array}$ & $\begin{array}{l}1.414 \pm \\
0.202\end{array}$ & $\begin{array}{l}1.300 \pm \\
0.186\end{array}$ & $\begin{array}{l}1.437 \pm \\
0.204\end{array}$ & $1.6 \pm 0.4 \mathrm{E}+0$ \\
\hline 02106279409 & $\mathrm{U}$ & $\mathbf{U}$ & $\mathrm{U}$ & $\mathbf{U}$ & $\mathbf{U}$ & $\mathbf{U}$ & $\begin{array}{l}1.482 \pm \\
0.205\end{array}$ & $\begin{array}{l}0.072 \pm \\
0.024\end{array}$ & $\begin{array}{l}1.270 \pm \\
0.178\end{array}$ & $\begin{array}{l}1.592 \pm \\
0.223\end{array}$ & $\begin{array}{l}1.426 \pm \\
0.202\end{array}$ & $\begin{array}{l}1.529 \pm \\
0.215\end{array}$ & $3.4 \pm 0.4 \mathrm{E}+0$ \\
\hline 02106279410 & $\mathbf{U}$ & $\mathbf{U}$ & $\begin{array}{l}0.032 \pm \\
0.016\end{array}$ & $\mathbf{U}$ & $\mathbf{U}$ & $\mathbf{U}$ & $\begin{array}{l}1.216 \pm \\
0.165\end{array}$ & $\begin{array}{l}0.063 \pm \\
0.019\end{array}$ & $\begin{array}{l}1.273 \pm \\
0.171\end{array}$ & $\begin{array}{l}2.347 \pm \\
0.338\end{array}$ & $\begin{array}{l}2.232 \pm \\
0.322\end{array}$ & $\begin{array}{l}2.304 \pm \\
0.333\end{array}$ & $1.3 \pm 0.4 \mathrm{E}+0$ \\
\hline 02106279411 & $\mathbf{U}$ & $\mathbf{U}$ & $\begin{array}{l}0.050 \pm \\
0.019\end{array}$ & $\mathbf{U}$ & $\mathbf{U}$ & $\mathbf{U}$ & $\begin{array}{l}1.309 \pm \\
0.174\end{array}$ & $\begin{array}{l}0.068 \pm \\
0.018\end{array}$ & $\begin{array}{l}1.234 \pm \\
0.165\end{array}$ & $\begin{array}{l}1.462 \pm \\
0.211\end{array}$ & $\begin{array}{l}1.349 \pm \\
0.195\end{array}$ & $\begin{array}{l}1.511 \pm \\
0.217\end{array}$ & $2.1 \pm 0.4 \mathrm{E}+0$ \\
\hline 02106279412 & UJ & $\begin{array}{l}0.014 \pm \\
0.007\end{array}$ & $\begin{array}{l}0.032 \pm \\
0.016\end{array}$ & $\mathbf{U}$ & $\mathbf{U}$ & $U$ & $\begin{array}{l}1.164 \pm \\
0.155\end{array}$ & $\begin{array}{l}0.047 \pm \\
0.015\end{array}$ & $\begin{array}{l}1.212 \pm \\
0.161\end{array}$ & $\begin{array}{l}1.464 \pm \\
0.229\end{array}$ & $\begin{array}{l}1.336 \pm \\
0.209\end{array}$ & $\begin{array}{l}1.300 \pm \\
0.205\end{array}$ & $3.3 \pm 0.6 \mathrm{E}+0$ \\
\hline 02106279413 & UJ & $\begin{array}{l}0.016 \pm \\
0.009\end{array}$ & $\mathbf{U}$ & $\mathbf{U}$ & $\begin{array}{l}0.020 \pm \\
0.009\end{array}$ & $\mathbf{U}$ & $\begin{array}{l}1.405 \pm \\
0.183\end{array}$ & $\begin{array}{l}0.070 \pm \\
0.018\end{array}$ & $\begin{array}{l}1.243 \pm \\
0.164\end{array}$ & $\begin{array}{l}1.300 \pm \\
0.208\end{array}$ & $\begin{array}{l}1.225 \pm \\
0.195\end{array}$ & $\begin{array}{l}1.261 \pm \\
0.200\end{array}$ & $5.9 \pm 0.6 \mathrm{E}+0$ \\
\hline 02106279414 & J & $\begin{array}{l}0.007 \pm \\
0.005\end{array}$ & $\begin{array}{l}0.043 \pm \\
0.014\end{array}$ & $\begin{array}{l}0.041 \pm \\
0.016\end{array}$ & $\begin{array}{l}0.032 \pm \\
0.018\end{array}$ & $\mathbf{U}$ & $\begin{array}{l}1.450 \pm \\
0.194\end{array}$ & $\begin{array}{l}0.086 \pm \\
0.023\end{array}$ & $\begin{array}{l}1.351 \pm \\
0.182\end{array}$ & $\begin{array}{l}1.559 \pm \\
0.239\end{array}$ & $\begin{array}{l}1.387 \pm \\
0.214\end{array}$ & $\begin{array}{l}1.502 \pm \\
0.230\end{array}$ & $1.2 \pm 0.4 \mathrm{E}+0$ \\
\hline
\end{tabular}


Table 3. (continued).

\begin{tabular}{|c|c|c|c|c|c|c|c|c|c|c|c|c|c|}
\hline $\begin{array}{l}\text { Sample } \\
\text { number }\end{array}$ & ${ }^{241} \mathrm{Am}$ & ${ }^{243} \mathrm{Am}$ & ${ }^{242} \mathrm{Cm}$ & ${ }^{244} \mathrm{Cm}$ & ${ }^{238} \mathrm{Pu}$ & $239 / 240_{\mathrm{Pu}}$ & ${ }^{234} \mathrm{U}$ & ${ }^{235_{U}}$ & ${ }^{238}{ }_{U}$ & ${ }^{228} \mathrm{Th}$ & ${ }^{230} \mathrm{Th}$ & ${ }^{232} \mathrm{Th}$ & ${ }^{90} \mathrm{Sr}$ \\
\hline 02106279415 & $\mathrm{~J}$ & U & $\mathbf{U}$ & $U$ & $\mathrm{U}$ & $U$ & $\begin{array}{l}1.396 \pm \\
0.187\end{array}$ & $\begin{array}{l}0.056 \pm \\
0.019\end{array}$ & $\begin{array}{l}1.387 \pm \\
0.186\end{array}$ & $\begin{array}{l}1.347 \pm \\
0.215\end{array}$ & $\begin{array}{l}1.302 \pm \\
0.208\end{array}$ & $\begin{array}{l}1.336 \pm \\
0.212\end{array}$ & $\mathbf{U}$ \\
\hline 02106279416 & J & $\begin{array}{l}0.014 \pm \\
0.009\end{array}$ & $\begin{array}{l}0.036 \pm \\
0.016\end{array}$ & $\mathrm{U}$ & $\begin{array}{l}0.043 \pm \\
0.021\end{array}$ & $\begin{array}{l}0.011 \pm \\
0.011\end{array}$ & $\begin{array}{l}1.248 \pm \\
0.168\end{array}$ & $\begin{array}{l}0.059 \pm \\
0.017\end{array}$ & $\begin{array}{l}1.189 \pm \\
0.161\end{array}$ & $\begin{array}{l}1.667 \pm \\
0.259\end{array}$ & $\begin{array}{l}1.293 \pm \\
0.205\end{array}$ & $\begin{array}{l}1.514 \pm \\
0.237\end{array}$ & $3.7 \pm 0.8 \mathrm{E}+0$ \\
\hline 02106279417 & UJ & $\mathbf{U}$ & U & $\mathbf{U}$ & $U$ & $U$ & $\begin{array}{l}1.140 \pm \\
0.153\end{array}$ & $\begin{array}{l}0.061 \pm \\
0.017\end{array}$ & $\begin{array}{l}1.225 \pm \\
0.163\end{array}$ & $\begin{array}{l}1.802 \pm \\
0.275\end{array}$ & $\begin{array}{l}1.437 \pm \\
0.224\end{array}$ & $\begin{array}{l}1.646 \pm \\
0.253\end{array}$ & $1.6 \pm 0.5 \mathrm{E}+0$ \\
\hline 02106279418 & UJ & $\mathbf{U}$ & $\begin{array}{l}0.038 \pm \\
0.016\end{array}$ & $\begin{array}{l}0.027 \pm \\
0.018\end{array}$ & $\mathrm{U}$ & $\mathrm{U}$ & $\begin{array}{l}1.498 \pm \\
0.199\end{array}$ & $\begin{array}{l}0.074 \pm \\
0.020\end{array}$ & $\begin{array}{l}1.248 \pm \\
0.168\end{array}$ & $\begin{array}{l}1.491 \pm \\
0.238\end{array}$ & $\begin{array}{l}1.475 \pm \\
0.235\end{array}$ & $\begin{array}{l}1.446 \pm \\
0.231\end{array}$ & $6.5 \pm 0.6 \mathrm{E}+0$ \\
\hline 02106279420 & UJ & $\mathrm{U}$ & $\begin{array}{l}0.038 \pm \\
0.014\end{array}$ & $\begin{array}{l}0.020 \pm \\
0.016\end{array}$ & $\mathbf{U}$ & $U$ & $\begin{array}{l}1.081 \pm \\
0.144\end{array}$ & $\begin{array}{l}0.056 \pm \\
0.0\end{array}$ & $\begin{array}{l}1.189 \pm \\
0.159\end{array}$ & $\begin{array}{l}1.435 \pm \\
0.210\end{array}$ & $\begin{array}{l}1.502 \pm \\
0.217\end{array}$ & $\begin{array}{l}1.387 \pm \\
0.202\end{array}$ & $1.7 \pm 0.4 \mathrm{E}+0$ \\
\hline 02106279421 & $\mathbf{U}$ & $\mathrm{U}$ & $\begin{array}{l}0.027 \pm \\
0.014\end{array}$ & $\begin{array}{l}0.023 \pm \\
0.016\end{array}$ & $\begin{array}{l}0.016 \pm \\
0.009\end{array}$ & $\mathbf{U}$ & $\begin{array}{l}1.259 \pm \\
0.170\end{array}$ & $\begin{array}{l}0.072 \pm \\
0.020\end{array}$ & $\begin{array}{l}1.392 \pm \\
0.187\end{array}$ & $\begin{array}{l}1.660 \pm \\
0.240\end{array}$ & $\begin{array}{l}1.309 \pm \\
0.192\end{array}$ & $\begin{array}{l}1.414 \pm \\
0.206\end{array}$ & $2.2 \pm 0.4 \mathrm{E}+0$ \\
\hline
\end{tabular}

$\stackrel{+}{\perp}$

$\mathrm{U}=$ Result is a statistical nondetect at the $95 \%$ confidence level.

$\mathrm{J}=$ Result is considered to be an estimated quantity because of questionable or out-of-control quality control parameter. Result is statistically positive at the $95 \%$ confidence level.

UJ = Result does not meet the criteria for statistically positive value at the $95 \%$ confidence level and is considered to be an estimated quantity because of a questionable or out-of-control quality control parameter. 
Table 4. Results of Phase II gamma spectrum analysis.

\begin{tabular}{|c|c|c|}
\hline Sample ID & $\begin{array}{l}\text { Manmade } \\
\text { radionuclides }\end{array}$ & $\begin{array}{c}\text { Activity } \\
\text { (pCi/gram) }\end{array}$ \\
\hline 02108019401 & ${ }^{137} \mathrm{Cs}$ & $7.0 \pm 2.0 \mathrm{E}-02$ \\
\hline 02108019402 & ${ }^{137} \mathrm{Cs}$ & $6.4 \pm 1.9 \mathrm{E}-02$ \\
\hline 02108019403 & None detected ${ }^{\mathrm{a}}$ & N/A \\
\hline 02108019404 & None detected ${ }^{\mathrm{a}}$ & N/A \\
\hline 02108019405 & ${ }^{137} \mathrm{Cs}$ & $3.1 \pm 0.3 \mathrm{E}-01$ \\
\hline 02108019405R & None detected ${ }^{\mathrm{a}}$ & N/A \\
\hline 02108019406 & ${ }^{137} \mathrm{Cs}$ & $2.0 \pm 0.4 \mathrm{E}-01$ \\
\hline 02108019407 & ${ }^{137} \mathrm{Cs}$ & $3.1 \pm 0.4 \mathrm{E}-01$ \\
\hline 02108019408 & ${ }^{137} \mathrm{Cs}$ & $2.4 \pm 0.3 \mathrm{E}-01$ \\
\hline 02108019409 & ${ }^{137} \mathrm{Cs}$ & $6.5 \pm 1.6 \mathrm{E}-02$ \\
\hline 02108019410 & ${ }^{137} \mathrm{Cs}$ & $9.0 \pm 2.0 \mathrm{E}-02$ \\
\hline 02108019411 & ${ }^{60} \mathrm{Co}$ & $9.5 \pm 1.8 \mathrm{E}-02$ \\
\hline 02108019412 & ${ }^{60} \mathrm{Co}$ & $9.4 \pm 1.8 \mathrm{E}-02$ \\
\hline 02108019413 & None detected ${ }^{\mathrm{a}}$ & N/A \\
\hline 02108019414 & None detected ${ }^{\mathrm{a}}$ & N/A \\
\hline 02108019415 & None detected ${ }^{\mathrm{a}}$ & N/A \\
\hline 02108019416 & ${ }^{137} \mathrm{Cs}$ & $5.5 \pm 1.9 \mathrm{E}-02$ \\
\hline 02108019417 & ${ }^{137} \mathrm{Cs}$ & $1.0 \pm 0.3 E-01$ \\
\hline 02108019418 & None detected ${ }^{a}$ & N/A \\
\hline 02108019419 & None detected ${ }^{a}$ & N/A \\
\hline 02108019420 & None detected ${ }^{a}$ & N/A \\
\hline 02108019421 & ${ }^{137} \mathrm{Cs}$ & $10.0 \pm 2.0 \mathrm{E}-02$ \\
\hline
\end{tabular}

a. No man-made gamma-emitting radionuclide contaminants were detected above background. 
Table 5. Results of Phase II strontium-90 and alpha spectrum analyses (pCi/g).

\begin{tabular}{|c|c|c|c|c|c|c|c|c|c|c|c|c|c|}
\hline $\begin{array}{l}\text { Sample } \\
\text { number }\end{array}$ & ${ }^{90} \mathrm{Sr}$ & ${ }^{241} \mathrm{Am}$ & ${ }^{243} \mathrm{Am}$ & ${ }^{242} \mathrm{Cm}$ & ${ }^{244} \mathrm{Cm}$ & ${ }^{238} \mathrm{Pu}$ & $239 / 240_{\mathrm{Pu}}$ & ${ }^{234} \mathrm{U}$ & ${ }^{235} \mathrm{U}$ & ${ }^{238} \mathrm{U}$ & ${ }^{228}$ Th & ${ }^{230} \mathrm{Th}$ & ${ }^{232} \mathrm{Th}$ \\
\hline $\begin{array}{c}02108019412 \\
\text {. }\end{array}$ & $\mathrm{U}$ & UJ & $\mathrm{U}$ & $\mathbf{U}$ & $\mathbf{U}$ & U & $\mathbf{U}$ & $\begin{array}{l}1.032 \pm \\
0.143\end{array}$ & $\begin{array}{l}0.032 \pm \\
0.014\end{array}$ & $\begin{array}{l}0.164 \pm \\
0.159\end{array}$ & $\begin{array}{l}1.367 \pm \\
0.246\end{array}$ & $\begin{array}{l}1.374 \pm \\
0.244\end{array}$ & $\begin{array}{l}1.286 \pm \\
0.233\end{array}$ \\
\hline 02108019416 & $\mathrm{U}$ & UJ & $\mathbf{U}$ & $\mathbf{U}$ & $\begin{array}{l}0.018 \pm \\
0.011\end{array}$ & $\mathbf{U}$ & $U$ & $\begin{array}{l}1.052 \pm \\
0.142\end{array}$ & $\begin{array}{l}0.034 \pm \\
0.014\end{array}$ & $\begin{array}{l}1.079 \pm \\
0.146\end{array}$ & $\begin{array}{l}0.300 \pm \\
0.220\end{array}$ & $\begin{array}{l}1.322 \pm \\
0.221\end{array}$ & $\begin{array}{l}1.297 \pm \\
0.219\end{array}$ \\
\hline $\mathbf{U}$ & Result is & tistical no & idetect at & $95 \%$ con & idence level. & & & & & & & & \\
\hline UJ & $\begin{array}{l}\text { Result doe } \\
\text { questionab }\end{array}$ & $\begin{array}{l}\text { ot meet th } \\
\text { blank cond }\end{array}$ & $\begin{array}{l}\text { criteria f } \\
\text { tion. }\end{array}$ & statisticall & positive val & we at the 9 & $\%$ confidence & level and & considered & be an est & lated quan & $y$ because & \\
\hline
\end{tabular}


In addition to the radiological analyses of samples collected during Phase $I$, an area survey was performed using the GPRS. The results of this area survey indicated nothing detected above general background ( $8 \mu \mathrm{R} / \mathrm{hour})$ at the CFA-669 site.

\subsubsection{Chemical Results}

The Phase II samples were analyzed for TCLP metals, TCLP VOCs, and TCLP semi-VOCs. The results of these analyses were validated by the EG\&G Idaho SMO. A review of the analytical results was performed by LITCO Environmental Monitoring. The review indicated that all contaminant concentrations were below the regulatory level found in 40 CFR 261.24, Table 1. The analytical and validation results are on file at the ARDC. 


\section{REFERENCES}

1. K. J. Liekhus, Characterization and Decision Analysis for the Old Hot Laundry Facility (CFA-669), EGG-10034, EG\&G Idaho, Inc., May 1992.

2. J. Light, Sampling and Analysis Plan for Sampling of Soil at CFA-669, ER-94-038, EG\&G Idaho, Inc., May 1994. 